\title{
PENGARUH KEPADATAN HELICOBACTER SPP DAN DERAJAT INFLAMASI TERHADAP KERUSAKAN HISTOPATOLOGIK PADA GASTRITIS KRONIK: REEVALUASI ARSIP SLIDE GASTRITIS KRONIK DI LABORATORIUM PATOLOGI ANATOMI RSUP DR KARIADI TH 2011-2013
}

\author{
Eny Dyah Kurniawati, Udadi Sadhana, Indra Wijaya \\ Bagian Patologi Anatomi Fakultas Kedokteran Universitas Diponegoro / RSUP Dr.Kariadi, \\ Jl. Dr. Sutomo 16-18 Semarang \\ Korespondensi: Eny Dyah Kurniawati \\ email: enydyahk@gmail.com
}

\begin{abstract}
ABSTRAK
Infeksi Helicobacter pylorii (Hp) telah menjadi masalah kesehatan yang mendunia, sebagai penyebab utama gastritis kronik, tukak lambung dan keganasan, akan tetapi mekanismenya dalam menimbulkan gastritis kronik masih belum sepenuhnya dimengerti. Penelitian ini bertujuan untuk mengetahui pengaruh kepadatan kuman Helicobacter spp dan derajad inflamasi terhadap derajat kerusakan histopatologik pada penderita gastritis kronik serta prevalensinya di RSUP dr.Kariadi. Penelitian ini adalah penelitianobservasional dengan pendekatan potong lintang dengan sampel sebanyak 70 slide arsip dari laboratorium Patologi Anatomi RSUP dr.Kariadi mulai 1 Januari 2011 - 31 Desember 2013 yang telah didiagnosis sebagai gastritis kronik disertai kuman Helicobacter spp positif oleh dokter spesialis Patologi Anatomi. Data kepadatan kuman Helicobacter spp, derajat inflamasi dan derajat kerusakan histopatologik gaster dianalisa dengan uji Kruskal Wallis, dilanjutkan dengan uji Mann-Whitney U dan uji korelasi Spearman. Prevalensi gastritis kronik dengan kuman Helicobacter spp positif di RSUP dr.Kariadi pada tahun 2011 sebesar 58\%, tahun 2012 naik menjadi 70\% dan tahun 2013 menjadi 79\%. Terdapat perbedaan yang tidak bermakna antara derajat kepadatan kuman Helicobacter spp dengan derajat inflamasi baik aktif maupun kronik dengan korelasi positif yang lemah dan perbedaan yang bermakna pada atrofi kelenjar yang merupakan bagian dari derajat kerusakan histopatologik gaster dengan korelasi positif yang lemah pada penderita gastritis kronik. Terdapat perbedaan yang signifikan antara derajat inflamasi baik aktif maupun kronik dengan derajat perubahan histopatologik dengan korelasi positif pada penderita gastritis kronik. Derajad inflamasi yang terjadi pada gastritis kronik akibat kuman Helicobacter spp berpengaruh pada derajat kerusakan histologik pada penderita gastritis kronik.
\end{abstract}

Kata kunci : Kepadatan kuman Helicobacter spp, derajat inflamasi, derajat kerusakan histopatollogik, gastritis kronik.

\section{ABSTRACT}

Helicobacter pylorii (Hp) infection has became a worldwide health problem, as a main cause of chronic gastritis, gastric ulcer and malignancies, but the mechanisms to make the diseases had not fully understood. This study aimed to analize the effect of Helicobacter spp density and inflammation degree to histopatological damage of chronic gastritis and its prevalence in dr.Kariadi Hospital.It was an observational study with cross sectional design, 70 archive slides from Laboratory of Anatomic Pathology dr. Kariadi Hospital from January 1, 2011 December 31, 2013 that had been diagnosed as chronic gastritis with Helicobacter spp positive by pathologist. The datas of Helicobacter spp degree, degree of inflammation, and degree of histopathological damage were analised by Kruskal Wallis test, Mann-Whitney U test and Spearman's correlation test. The prevalence of chronic gastritis with positive Helicobacter spp in dr. Kariadi Hospital at 2011 was 58\%, 70\% at 2012 and increased as 79\% at 2013. There was a difference but statistically not significant among Helicobacter spp densities and the 
degree of active and chronic inflammation with weak correlation and also a statistically significant difference and correlation for glandular atrophy as a part of gastric histopathological damage. There were statistically significant difference among active and chronic infammation to degree of histopathological damage with positively correlation in chronic gastritis. The degree of inflammation in Helicobacter spp related chronic gastritis effects the degree of histopathological damage in chronic gastrittis.

Keywords: Helicobacter spp densities, degree of inflammation, degree of histopathological damage, chronic gastritis

\section{PENDAHULUAN}

Infeksi Helicobacter pylorii (Hp) telah menjadi masalah di seluruh dunia karena diduga menjadi salah satu penyebab utama dari gastritis kronik, tukak lambung, kanker lambung dan limfoma pada saluran cerna. Peran $\mathrm{Hp}$ dalam penyakit diatas telah diketahui sejak 1983 oleh Marshal dan Warren, tapi sampai sekarang masih menjadi masalah karena patogenesis $\mathrm{Hp}$ dalam menyebabkan penyakit diatas masih belum jelas (Lehours \& Yilmaz, 2007; Redeen . 2010; Syaifudin, 2008). Prevalensi gastritis kronik yang disebabkan oleh infeksi Hp di Indonesia sebesar 36-46,1\% (Syaifudin, 2008). Sedangkan di RSUP dr.Kariadi Semarang sebesar 50-79\% sejak tahun 2011-2013 dengan kenaikan sebanyak 0,85\% pertahun.

Salah satu patogenesis terjadinya penyakit gastritis kronis pada infeksi $\mathrm{Hp}$ adalah menimbulkan inflamasi. Terdapat dua mekanisme terjadinya inflamasi gaster, yaitu melalui mekanisme pertama dengan merusak lapisan epitel secara langsung dan mekanisme kedua dengan merangsang respon imunitas baik imunitas non spesifik maupun spesifik (Bodger \&Crabtree, 1998; Kumaret al, 2010). Inflamasi yang terjadi bertujuan untuk mengeradikasi kuman $\mathrm{Hp}$, akan tetapi efek samping dari inflamasi tersebut memperparah kerusakan jaringan akibat dari pelepasan enzym lisosom serta reactive oxygen dan nitrogen species yang dilepaskan oleh netrofil dan makrofag(Kumaret al, 2010).

Pengaruh kepadatan kuman Hp dengan kerusakan epitel permukaan dan inflamasi telah banyak diteliti, namun bagaimana derajad inflamasi akibat kuman Hp terhadap kerusakan epitel permukaan gaster belum banyak diteliti (Atherton et al, 1996; Bhat et al, 2005; Bodger\& Crabtree, 1998;D'Elios \& Andersen, 2007; Elseweidyet al, 2010; Lehours \& Yilmaz, 2007; McNamaraa \& El-Omar, 2008; Mitchell, 2001;
Moss \&Malfertheiner, 2007; Parket al, 2008; Scanzianiet al, 2001; Wang et al, 2000; Wang et al, 2001; Wroblewskiet al, 2009). Pada penelitian ini, peneliti ingin melihat pengaruh derajat kepadatan kuman Helicobacter spp terhadap derajat inflamasi dalam hal ini sebukan lekosit polimorfonuklear dan mononuklear serta bagaimana pengaruh derajad inflamasi yang terjadi pada gastritis kronik akibat kuman Helicobacter spp terhadap perubahan histopatologik mukosa gaster, dalam hal ini atrofi, metaplasia dan displasia pada penderita gastritis kronik di RSUP dr.Kariadi Semarang.

\section{METODE}

Penelitian ini merupakan penelitian observasional dengan pendekatan potong lintang. Sampel yang digunakan adalah slide HE dan slide yang dicat dengan pengecatan khusus Giemsa atau Diff Quik dari 70 pasien gastritis kronik dengan kuman Helicobacter spp positif yang berasal dari arsip slide Laboratorium Patologi Anatomi RSUP dr. Kariadi th 2011-2013. Slide -slide tersebut kemudian direevaluasi kembali dengan mengacu pada ketentuan dari sistem Sidney,oleh dua orang patolog. Data yang diperoleh antara lain kepadatan kuman Helicobacter spp, derajat inflamasi, derajat atrofi, derajat metaplasia dan derajat displasia yang ditemukan. Kepadatan kuman Helicobacter spp, derajat inflamasi dan derajat atrofi dinilai dengan menggunakan skala visual analog yang dipaparkan oleh Dixon (2001). Derajat metaplasia dinilai dengan menggunakan Sistem OLGA (Operative Link for Gastritis Assesment) seperti yang dinyatakan oleh Rugee (2005). Derajat displasia dinilai seperti pada penilaian displasia pada esofagus (Montgomery, 2006). Penelitian ini telah mendapatkan ethical clearance dari Komisi Etik Penelitian Kesehatan Fakultas Kedokteran Undip/RSUP dr.Kariadi no 050/EC/FK-RSDK/2014. 
HASIL DAN PEMBAHASAN

Pengaruh kepadatan kuman Helicobacter spp terhadap derajat inflamasi dan kerusakan histopatologik jaringan gaster.

Tabel 1. Pengaruh kepadatan kuman Helicobacter spp terhadap derajat inflamasi dan kerusakan histopatologik jaringan gaster

\begin{tabular}{lllll}
\hline $\begin{array}{c}\text { Kepadatan kuman } \\
\begin{array}{c}\text { Helicobacter spp } \\
\text { terhadap: }\end{array}\end{array}$ & $\begin{array}{c}\text { Uji beda } \\
\text { Kruskal } \\
\text { Wallis }\end{array}$ & Uji beda Mann Whitney U & $\begin{array}{c}\text { Uji korelasi } \\
\text { Rank } \\
\text { Spearman }\end{array}$ & Kemaknaan \\
\hline $\begin{array}{lllll}\text { Inflamasi aktif } \\
\text { Inflamasi kronik }\end{array}$ & $\begin{array}{l}\mathrm{p}=0,56 \\
p=0,069\end{array}$ & & $\mathrm{r}=0,232$ & $\mathrm{p}=0,053$ \\
Atrofi & $p=0,033$ & $\begin{array}{l}\text { kuman Helicobacter spp } \\
\text { ringan-sedang } p=0.045\end{array}$ & $\mathrm{r}=0,314$ & $p=0.022$ \\
& & $\begin{array}{l}\text { Ringan-berat } p=0.045 \\
\text { Metaplasia Intestinal }\end{array}$ & & \\
Displasia & $p=0,156$ & & $\mathrm{r}=0.152$ & $p=0.209$ \\
\hline & $p=0,813$ & & $\mathrm{r}=0.073$ & $p=0.551$ \\
\hline
\end{tabular}

Pengaruh inflamasi aktif terhadap inflamasi kronik dan kerusakan histopatologik.

Tabel 2. Pengaruh inflamasi aktif terhadap inflamasi kronik dan kerusakan histopatologik

\begin{tabular}{lrlll}
\hline $\begin{array}{c}\text { Derajat Inflamasi } \\
\text { aktif terhadap: }\end{array}$ & $\begin{array}{c}\text { Uji beda } \\
\text { Kruskal } \\
\text { Wallis }\end{array}$ & \multicolumn{1}{c}{ Uji beda Mann Whitney $\mathrm{U}$} & $\begin{array}{c}\text { Uji korelasi } \\
\text { Rank Spearman }\end{array}$ & Kemaknaan \\
\hline Inflamasi kronik & $p=0,032$ & $\begin{array}{l}\text { inflamasi aktif ringan - moderat } \\
p=0,024\end{array}$ & $\mathrm{r}=0,316$ & $p=0,008$ \\
Atrofi & $p=0,000$ & $\begin{array}{l}\text { inflamasi aktif } \\
\text { Ringan-moderat } p=0,000 \\
\text { Ringan-berat } p=0,044\end{array}$ & $p=0,000$ \\
Metaplasia Intestinal & $p=0,046$ & $\begin{array}{l}\text { inflamasi aktif } \\
\text { ringan - berat } p=0,014 \\
\text { inflamasi aktif } \\
\text { ringan moderat } p=0,017\end{array}$ & $\mathrm{r}=0.267$ & $p=0,025$ \\
Displasia & $p=0,028$ & $\mathrm{r}=0.322$ & $p=0,007$ \\
\hline
\end{tabular}

Pengaruh derajat inflamasi kronik terhadap kerusakan histopatologik.

Tabel 3. Pengaruh derajat inflamasi kronik terhadap kerusakan histopatologik

\begin{tabular}{|c|c|c|c|c|}
\hline $\begin{array}{l}\text { Derajat Inflamasi } \\
\text { kronik terhadap: }\end{array}$ & $\begin{array}{l}\text { Uji beda } \\
\text { Kruskal } \\
\text { Wallis }\end{array}$ & Uji beda Mann Whitney U & $\begin{array}{l}\text { Uji korelasi Rank } \\
\text { Spearman }\end{array}$ & Kemaknaan \\
\hline Atrofi & $p=0,000$ & $\begin{array}{l}\text { Inflamasi kronik }= \\
\text { Ringan -sedang } p=0,001 \\
\text { Ringan-berat } p=0,001 \\
\text { Sedang-berat } p=0,044\end{array}$ & $\mathrm{r}=0,492$ & $p=0,000$ \\
\hline Metaplasia Intestinal & $p=0,013$ & $\begin{array}{l}\text { inflamasi kronik }= \\
\text { Ringan }- \text { sedang } p=0,019\end{array}$ & $\mathrm{r}=0.356$ & $p=0,003$ \\
\hline Displasia & $p=0,018$ & $\begin{array}{l}\text { Inflamasi kronik }= \\
\text { Ringan-berat } p=0,027 \\
\text { Sedang-berat } p=0,008\end{array}$ & $\mathrm{r}=0.229$ & $p=0,057$ \\
\hline
\end{tabular}


Infeksi kuman Hp merupakan masalah dunia sebagai penyebab dari gastritis kronik dengan prevalensi yang bervariasi ditiap negara. Pada umumnya di negara berkembang lebih tinggi dibandingkan di negara maju (Dunn et al, 1997; Duynhoven \& Jonge, 2001). Di Indonesia prevalensinya mencapai $36-46,1 \%$, di Surabaya mencapai 85,7-93,9\%, bahkan di Jakarta mencapai 100\% (Syaifudin, 2008). Prevalensi di RSUP dr.Kariadi menunjukkan kecenderungan meningkat sebesar $0,85 \%$ setiap tahun mulai tahun 2011. Tahun 2011 sebesar 59\%, tahun 2012 naik menjadi 69\% dan tahun 2013 menjadi 79\% (Eny, 2014). Angka prevalensi ini meningkat sangat tajam dibandingkan pada tahun 2005 yang hanya sebesar 2\% (Tokudome et al, 2005).

\section{Pengaruh Derajat Kepadatan Kuman Helico- bacter Sppdengan Derajat Inflamasi dan Keru- sakan Histopatologik}

Infeksi kuman Helicobacter spp menimbulkan inflamasi baik aktif maupun kronik pada mukosa gaster (Dixon et al, 1996). Pada penelitian ini, ditemukan infiltrasi PMN pada seluruh sampel jaringan biopsi gaster (100\%), dengan derajat yang bervariasi, terbanyak berderajat ringan (43\%). Inflamasi kronik yang ditemukan terbanyak berderajat moderat $(43 \%)$. Pada penelitian ini tidak didapatkan adanya perbedaan derajat inflamasi aktif maupun kronik yang bermakna $(p \geq 0,05)$ yang ditimbulkan oleh kepadatan kuman Helicobacter spp pada gastritis kronik. Hal ini bisa disebabkan oleh variasi virulensi kuman maupun variasi kuman Helicobacter spp yang menginfeksi. Bhat menyatakan pada strain kuman Hp yang memiliki Cag positif menimbulkan respon inflamasi yang lebih berat dibandingkan strain kuman $\mathrm{Hp}$ dengan Cag negatif (Bhat et al, 2005). Atherton menyatakan hal yang serupa pada strain $\mathrm{Hp}$ dengan Cag dan VacA positif (Atherton et al, 2001). Scanziani (2001) menyatakan pada infeksi kuman Helicobacter heilmannii dan kuman Helicobacter spp yang tidak terklasifikasi, menimbulkan respon inflamasi sel radang mononuklear yang minimal.

Infeksi kuman Helicobacter spp pada gaster merusak morfologi mukosa gaster melalui tiga cara yaitu efek langsung virulensi kuman, inflamasi dan radikal bebas (Reuse \&Skouloubris, 2001). Kerusakan morfologi mukosa gaster tersebut oleh acuan diagnosis The Sydney Sistem dibagi menjadi atrofi kelenjar dan metaplasia intestinal. Displasia merupakan variabel yang dilaporkan bila ditemukan( Dixon et al1996; Rugge \&Genta, 2005).Pada penelitian ini, sebagian besar jaringan biopsi gaster mengalami atrofi ringan $(31,4 \%)$. Didapatkan perbedaan derajat atrofi kelenjar yang bermakna $(p \leq 0,05)$ pada mukosa gaster dengan kepadatan kuman Helicobacter spp ringan dibanding moderat dan padat, serta korelasi positif $(\mathrm{r}=0,314)$ secara bermakna $(p \leq 0,01)$ antara kepadatan kuman Helicobacter spp terhadap derajat atrofi kelenjar.Pada infeksi kuman Helicobacter spp, atrofi kelenjar disebabkan oleh cedera mukosa yang berulang baik karena efek sitotoksin dan urease yang dihasilkan oleh bakteri maupun respon inflamasi tubuh yang kemudian digantikan oleh jaringan ikat (Dixon, 2001). HP0175, VacA, dan Urease menginduksi apoptosis epitel gaster (Atherton et al, 2001; Basak e al, 2005; Wroblewski et al, 2009)(11, 27,29). Pada penelitian ini, jaringan biopsi gaster yang mengalami metaplasia hanya $21,4 \%$ dengan derajat metaplasia terbanyak adalah ringan $10,0 \%$. Metaplasia yang ditemukan seluruhnya bertipe metaplasia intestinal. Kuman Helicobacter spp dapat secara langsung menimbulkan metaplasia intestinal melalui patogenesis sebagai berikut. CagA berinteraksi dengan $E$ cadherin yang terdapat pada sel epitel gaster mengganggu pembentukan kompleks $E$ cadherin - $\beta$ cathenin menyebabkan $\beta$ cathenin terkumpul di inti mengaktifkan gen CDX1, mengkode faktor transkripsi intestinal specific CDX1, memicu terjadinya metaplasia intestinal (Maeda \& Mentis, 2007). Dalam kondisi normal gen cdx-1 dan cdx-2 hanya diekspresikan di intestinal (Dixon, 2001). Selain atrofi dan metaplasia, pada penelitian ini juga ditemukan displasia sebanyak 21,4\%. Pada gastritis atropik yang telah berlangsung lama terutama yang disebabkan oleh kuman Hp, epitel yang mengalami metaplasia intestinal cenderung mengalami transformasi menjadi epitel yang dediferensiasi, yang masih terbatas di dalam basal membran kelenjar yang disebut dengan displasia (Rugge \& Genta, 2005).

\section{Pengaruh Inflamasi Terhadap Kerusakan His- topatologik \\ Pada penelitian ini kami membandingkan}


antara derajat inflamasi aktif dengan derajat atrofi kelenjar, dengan hasil didapatkan perbedaan yang bermakna antara derajat atrofi dengan derajat inflamasi ringan dan moderat/berat pada mukosa jaringan biopsi gaster. Dengan menggunakan uji korelasi Spearman tampak adanya korelasi positif $(r=0,488)$ yang signifikan $(\mathrm{p} \leq 0,01)$ antara derajat inflamasi aktif dengan derajat atrofi kelenjar.Sedangkan pada derajat inflamasi kronik didapatkan perbedaan derajat atrofi kelenjar yang bermakna dengan korelasi positif $(\mathrm{r}=0,492)$ yang signifikan $(p \leq 0,05)$.Didapatkan perbedaan derajat metaplasia yang bermakna antara mukosa jaringan gaster yang mengalami inflamasi aktif ringan dan berat $p=0,014$ dengan korelasi positif $(\mathrm{r}=0,267)$ yang signifikan $(\mathrm{p} \leq 0,05)$. Didapatkan juga perbedaan derajad metaplasia intestinal yang bermakna antara mukosa jaringan gaster yang mengalami inflamasi kronik ringan dan moderat $(p=0,019)$ serta tampak adanya korelasi positif $(\mathrm{r}=0,356)$ yang signifikan $(\mathrm{p} \leq 0,01)$ antara inflamasi kronik dengan metaplasia intestinal.Didapatkan perbedaan derajat displasia yang bermakna antara mukosa jaringan gaster yang mengalami inflamasi aktif ringan dan moderat $p=0,017$. Tampak adanya korelasi positif $(\mathrm{r}=0,322)$ yang signifikan $(p \leq 0,01)$ antara inflamasi aktif dengan displasia. Didapatkan juga perbedaan derajat displasia kelenjar yang bermakna antara mukosa jaringan gaster yang mengalami inflamasi kronik ringan dan moderat dibandingkan dengan mukosa jaringan gaster yang mengalami inflamasi kronik berat $(p \leq 0,05)$. Tampak adanya korelasi positif lemah $(0,229)$ tapi tidak signifikan $(\mathrm{p} \leq 0,01)$ antara inflamasi kronik dengan displasia.

Hal tersebut menunjukkan besarnya peranan inflamasi dalam menimbulkan kerusakan sel epitel gaster yang berakibat pada kerusakan struktur kelenjar mukosa gaster yang kemudian diikuti oleh proses fibrosis, metaplasia maupun displasia. Penyebab kerusakan tersebut bisa ditimbulkan oleh radikal bebas yang dihasilkan selama proses inflamasi, imunitas yang dimediasi oleh sel dan sitokin, imunitas humoral, maupun fibrosis(Kumar et al, 2010; Wang et al, 2000).

Berdasarkan temuan diatas, maka terapi gastritis kronik yang disebabkan oleh kuman Helicobacter spp tidak bisa hanya eradikasi kuman Hp saja, melainkan juga membutuhkan antioksidan dan antiinflamasi yang aman bagi mukosa lambung misalnya quercetin dan poliunsuturated fatty acid (PUFA) (Lee et al, 2014; Nairet al, 2006). Madu mengandung quercetin yang telah terbukti mempercepat penyembuhan gastritis baik akibat aspirin maupun kuman Helicobacter pylori (Dyah, 2014; Eny, 2014; Nzeako \& Al-Namaani, 2006).

\section{SIMPULAN}

Kepadatan kuman Helicobacter spp dan derajat inflamasi berpengaruh pada derajat kerusakan histopatologik pada penderita gastritis kronik.

\section{SARAN}

Pemberian antiinflamasi yang aman bagi lambung perlu ditambahkan pada terapi gastritis kronik yang disebabkan oleh kuman Helicobacter spp.

\section{DAFTAR PUSTAKA}

Atherton J, Cover T, Papini E, Telford J., 2001. Vacuolating cytotoxin. Washington DC: ASM Press

Atherton J, Tham K, RM Peek J, Cover T, Blaser M., 1996 Density of helicobacter pylori infection In vivo as assessed by quantitative culture and histology. J Inf Dis. 174:552-6.

Basak C, Pathak S, Bhattacharyya A, Pathak S, Basu J, Kundu M., 2005. The secreted peptidyl prolyl cis,trans-isomerase HP0175 of Helicobacter pylori induces apoptosis of gastric epithelial cells in a TLR4- and apoptosis signalregulating kinase 1-dependent manner. $J$ Immunol. 174:5672-80.

Bhat N, Gaensbauer J, Peek R, Bloch K, Tham K-T, Blaser M, et al. 2005. Local and systemic immune and inflammatory responses to helicobacter pylori strains. Clin Diagn Lab Immunol.12(12): 1393-400.

Bodger K, Crabtree J., 1998. Helicobacter pylori and gastric inflammation. $B M B, 54(1): 139-50$.

D’Elios M, Andersen L., 2007. Helicobacter pylori inflammation, immunity, and vaccines In: Graham D, (eds). Helicobacter, Blackwell Publishing; 18-21.

Dixon M., 2001.Pathology of gastritis and peptic ulceration. Washington DC: ASM Press.

Dixon M, Genta R, Yardley J, Correa P., 1996. Classification and grading of gastritis : the 
updated sydney system. Am J Surg Pathol, 20(10):1161-81.

Dunn B, Cohen H, Blaser MJ., 1997. Helicobacter pylori. Clin Microbiol Rev,10(4):720

Duynhoven YTHPv, Jonge Rd., 2001. Transmission of Helicobacter pylori: a role for food? Bulletin of the World Health Organization.79:455-60.

Dyah Ari N.,2014. Pengaruh madu multiflora terhadap skor gambaran histopatologi dan ekspresi cyclooxygenase (cox)-2 pada lambung tikus yang diinduksi aspirin (Thesis). Semarang: Universitas Diponegoro.

Elseweidy M, Taha M, Younis N, Ibrahim K, Hamouda $\mathrm{H}$, Eldosouky M, et al., 2010. Gastritis induced by Helicobacter pylori infection in experimental rats. Dig Dis Sci.55:2770-7

Eny DK., 2014.Pengaruh madu multiflora terhadap ekspresi vascular endothelial growth factor dan kepadatan kapiler pada lambung tikus wistar yang diinduksi aspirin (Thesis). Semarang: Universitas Diponegoro.

Eny DK.,2014.Pengaruh kepadatan Helicobacter spp dan derajat inflamasi terhadap kerusakan histopatologik pada gastritis kronik: reevaluasi arsip slide gastritis kronik di laboratorium patologi anatomi RSUP $d r$. kariadi th 2011-2013 (Thesis). Semarang: Diponegoro University

Kumar V, Abbas A, Fausto N, Aster J., 2010. Acute and chronic inflammation. In: Kumar V, Abbas A, Fausto N, Aster J, editors. Robbin and cotran pathologic basis of disease. 8th ed. New York: Saunders Elsevier:43-77

Kumar V, Abbas A, Fausto N, Aster J., 2010. Tissue renewal, repair and regeneration. In: Kumar V, Abbas A, Fausto N, Aster J, editors. Robbin and Cotran : pathologic basis and disease. Washington DC: Saunder Elsevier: 79-109.

.Lee SE, Lim JW, Kim JM, Kim H., 2014. AntiInflammatory Mechanism of Polyunsaturated Fatty Acids in Helicobacter pylori-Infected Gastric Epithelial Cells. Hindawi.12.

Lehours P, Yilmaz O. 2007. Helicobacter, Blackwell Publishing; 2007 [cited 2013 September 9].

Maeda S, Mentis A., 2007.Pathogenesis of Helicobacter pylori infection: Blackwell Publishing

McNamaraa D, El-Omar E., 2008. Helicobacter pylori infection and the pathogenesis of gastric cancer: A paradigm for host-bacterial interactions. Digestive and Liver Disease. 40:504-9.

Mitchell H., 2001. Epidemiology of infection, In:
Mobley H, Mendz G, Hazell S, editors. Helicobacter pylori: physiology and genetics. Washington DC: ASM Press

Montgomery E., 2006.Biopsy interpretation of the gastrointestinal tract mucosa. Hongkong: Lippincott Williams \& Wilkins

Moss S, Malfertheiner P., 2007.Helicobacter and gastric malignancies: Blackwell Publishing

Nair M, Mahajan S, Reynolds J, Aalinkeel R, Nair $\mathrm{H}$, Schwarts S, et al., 2006. The flavonoid quercetin inhibits proinflammatory cytokine (tumor necrosis factor alpha) gene expression in normal peripheral blood mononuclear cells via modulation of the NF-System. Clin Vaccine Immunol.13(3):319-28.

Nzeako B, Al-Namaani F., 2006. The antibacterial activity of honey on Helicobacter pylori. Sultan Qaboos University Medical Journal.6(2):71-5.

Park J-H, Seok S, Baek M, Lee H, Kim D, Park J-H., 2008. Gastric lesions and immune responses caused by long-term infection with helicobacter heilmannii in C57BL/6 mice. $J$ Comp Path.139:208-17

Redeen S., 2010.Chronic gastritis: diagnosis, natural history and consequences [Dissertation]. Linkoping: Linkoping University

Rugge M, Genta R., 2005. Staging and grading of chronic gastritis. Human Pathol.;36:228-33

Reuse H., 2001. Skouloubris S. Nitrogen metabolism: ASM Press

Scanziani E, Simpson K, Monestiroli S, Soldati S, Strauss-Ayali D, Piero FD. 2001. Histological and immunohistochemical detection of different Helicobacter species in the gastric mucosa of cats. J Vet Diagn Invest.13:3-12.

Smoot D, Elliott T, Verstpaget H, Jones D, Allen $\mathrm{C}$, Vernon $\mathrm{K}$, et al., 2000. Influence of Helicobacter pylori on reactive oxygen induced gastric epithelial injury. Carcinogenesis, 21(11):2091-95.

Syaifudin M., 2008. Pengembangan teknik biologi molekuler untuk deteksi Helicobacter pylori pada penderita dispepsia. Available from: http://nhc.batan.go.id/syaifudin1.php.

Tokudome S, Witjitra DS, Soeripto, Ediati T, Suzuki S, Teguh T, et al. 2005. Helicobacter pylori infection appears essential for stomach carcinogenesis: Observations in Semarang, Indonesia. CancerSci.96(12):873-5.

Wang J, Blanchard T, Ernst P., 2001. Host inflammatory respons to infection: ASM Press 
Wang J, Fan X, Lindholm C, Bennet M, J OC, Shanahan F, et al., 2000. Helicobacter pylori modulates lymphoepithelial cell interactions leading to epithelial cell damage through Fas/Fas ligand interactions. Infect Immun.68(7):4303-11.
Wroblewski L, Shen L, Ogden S, Romero-Gallo S, Lapierre L, Israel D, et al.,2009. Helicobacter pylori dysregulation of gastric epithelial tight junctions by urease-mediated myosin II activation. Gastroenterol,36(1):236-46. 